\title{
Corpos fragmentados e domesticados na reprodução assistida*
}

\author{
Martha Ramírez-Gálvez **
}

\section{Resumo}

Este artigo analisa os mecanismos de produção de sentido da infertilidade e dos novos modos de produção da vida, mediante o uso de tecnologias reprodutivas conceptivas. Destacam-se os pressupostos normativos de maternidade e/ou reprodução, assim como a relação do surgimento e configuração deste campo como um empreendimento contemporâneo de mercantilização $e$ consumo de biotecnologias. O progresso científico, neste caso, é incorporado na figura do tecno-embrião, ligado à fetichização do gene e à afirmação de valores tradicionais associados à família consangüínea.

Palavras-chave: Reprodução Assistida, Biotecnologia, Reprodução Humana, Consumo de Tecnologias, Família.

\footnotetext{
* Recebido para publicação em setembro de 2008, aceito em setembro de 2009. Uma versão anterior deste artigo foi publicada na Revista Nada, $n^{\circ} 9$, Portugal, 2007.

** Professora do Departamento de Ciências Sociais da Universidade Estadual de Londrina - Grupo de Pesquisa CTeMe/Unicamp. marthacerg@gmail.com
} 
Corpos fragmentados e domesticados na reprodução assistida

Fragmented and Domesticated Bodies in Assisted Reproduction

\begin{abstract}
This article analyzes the mechanisms of the production of the sense of infertility and of the new modes of production of life through the use of conceptive reproductive technologies. The normative underpinnings of maternity and/or reproduction are highlighted, as well as the emergence and taking shape of this field as a contemporary drive toward the mercantilization and consumption of biotechnology. Scientific progress, in this case, is incorporated into the figure of the techno-embryo, linked to the fetishization of the gene and the assertion of traditional values associated with consanguineous families.
\end{abstract}

Key Words: Assisted Reproduction, Biotechnology, Human Reproduction, Consumption of Technologies, Family. 


\section{Introdução}

O surgimento progressivo da grande medicina do século XIX não pode ser dissociado das políticas de saúde e da consideração das doenças como problema político e econômico. Tampouco pode se dissociar da compreensão da família, não só como um sistema de parentesco e de transmissão de bens, senão também como local de "fabricação", nas melhores condições possíveis, de um ser humano. A família se afirma, desde então, como um agente constante de medicalização. A medicina, especialmente depois das análises realizadas por Foucault, tem sido indicada como uma das instituições a partir da qual os sujeitos e suas práticas são normatizados (Foucault, 1996).

A maioria das análises que indaga a relação entre reprodução humana e medicina, revela a centralidade do corpo $e$ da sexualidade feminina como lugar, por excelência, de escrutínio e políticas de controle. As tentativas de colocar a descoberto os mistérios da reprodução parecem acompanhar a história da humanidade e suas explicações se articulam à interpretação do mundo vigente em cada época. Alguns autores apontam que, na apropriação do corpo feminino pelo saber médico, o desenvolvimento do conhecimento cirúrgico e tecnológico joga um papel determinante. A tecnologia médica atual se teria originado nos séculos XVI e XVII, época do racionalismo cartesiano e dos êxitos da física newtoniana, que promoveram a exacerbação dos mecanismos biológicos e o surgimento e consolidação do complexo médico industrial com seus interesses lucrativos (Barros, 1991).

Viera (1990) apud Barbosa (1999) observa que a legitimação dos cuidados do corpo feminino, como campo exclusivo da medicina, é produzida principalmente a partir do surgimento da obstetrícia, que deu lugar a outras disciplinas médicas como a ginecologia, a embriologia e a genética. Essa competência médica, instaurada nos séculos XVIII e XIX, expandiu-se com diversos 
desdobramentos, tomando o controle da concepção, da gravidez, do parto e da anticoncepção. A apropriação desses espaços por parte da medicina implicou na desapropriação da chamada medicina tradicional $e$ do conhecimento $e$ atuação leiga de agentes sociais, como as parteiras. Gravidez, parto e nascimento eram considerados, até então, eventos naturais do ciclo de vida. A medicalização do processo reprodutivo teve diversas implicações em vários âmbitos que deixamos aqui de lado para destacar a criação de um mercado farmacológico e diagnóstico, que cresceu paralelo ao gerenciamento da reprodução através do consumo de práticas médicas.

O surgimento da Reprodução Assistida (RA) - que inclui uma série de procedimentos médico-técnicos que possibilitam a realização de gestações que não aconteceriam espontaneamente - e a apropriação do desejo de filhos por parte da medicina são incluídos por Corrêa (2001) no processo de medicalização social. Esse termo designa a modificação da prática médica mediante a inovação de métodos diagnósticos e terapêuticos, da indústria farmacológica e de equipamentos médicos que tem como conseqüência um aumento exagerado no consumo de atos médicos e de medicamentos. Para Corrêa (2001:24):

Todos esses fenômenos submetidos à normalização médica discursiva acabam remetidos à intervenção de alguma prática especializada, sendo as novas tecnologias reprodutivas, com suas propostas de medicalizar a ausência de filhos, um dos exemplos mais recentes.

Barros (1991) destaca a crença das pessoas na necessidade de consumir o arsenal de diagnósticos e tratamentos para a solução de seus problemas, enquadrados como doença, como uma das conseqüências do modelo médico - ligado ao setor de insumos para o setor saúde da indústria farmacêutica e de equipamentos. Acredita-se, comumente, que quanto mais 
modernas e sofisticadas as tecnologias empregadas, maiores as promessas de sua efetividade.

A ideologia do consumo, que associa a idéia de inclusão, de sensação de "bem-estar" e "felicidade" ao ato de consumir, expande seus domínios na área de bens e serviços no campo da manutenção e/ou recuperação da saúde, no qual estes assumem o valor de "mercadorias" submetidas às leis do mercado. Essa lógica, presente na mercantilização da medicina, passa a ocupar espaços crescentes na vida dos indivíduos e da sociedade. A "medicalização da mulher" seria uma ilustração farta da transformação da vida em uma seqüência de eventos que demandam formas peculiares de consumo de bens, de serviços diagnósticos e terapêuticos que, em algumas ocasiões, pouco contribuem para um efetivo melhoramento na qualidade de vida (Barros, 1991). ${ }^{1}$

Eventos do ciclo de vida, redescritos em termos da medicina moderna, passam a serem situações nas quais a tecnologia age paliativamente, viabilizando a relação com os consumidores sem consciência quanto à determinação social da saúde e da doença. Essa redescrição coloca em jogo interesses envolvidos na própria produção de atos médicos que implicam a comercialização $e$ consumo de serviços, fármacos e equipamentos. Paralelamente, os efeitos desse processo redundam na produção de conhecimentos pela medicina, nas representações dos eventos medicalizados $e$ nos padrões de comportamento dos indivíduos.

Apresento a análise de narrativas sobre RA, destacando os pressupostos normativos de maternidade e/ou reprodução, assim como a relação do surgimento e configuração deste campo como empreendimento contemporâneo de mercantilização e consumo

\footnotetext{
1 São freqüentes as polêmicas em torno dos benefícios da supressão menstrual, da terapia de reposição hormonal na menopausa, entre outros, que questionam não só a efetividade de algumas terapêuticas, como também o desencadeamento de outros processos que podem chegar a requerer tratamentos mais complexos $e$ debilitadores. Para uma discussão sobre a supressão menstrual, ver Manica (2003).
} 
de biotecnologias, ligado à fetichização do gene e à afirmação de valores tradicionais associados à família consangüínea. Os dados apresentados aqui se concentram na análise de páginas eletrônicas e folhetos publicitários de clínicas, medicamentos e equipamentos para RA. ${ }^{2}$

\section{Corpos "sem Pessoa"}

O corpo tem sido fragmentado de diversas formas, através das várias tecnologias visuais que possibilitam a despersonalização e desumanização de pessoas em corpos ou, como indica Chazan (2002, 2007), o surgimento de corpos "sem Pessoa". Essa fragmentação, também presente na separação cartesiana de corpo/mente, adquire um outro desdobramento no sentido de possibilitar a mercantilização do corpo e de suas partes. Na RA, especificamente, observa-se a fragmentação do processo reprodutivo, através do qual se abre espaço para o surgimento de doação de gametas, que, de alguma forma, partilha questões relacionadas com a doação de órgãos.

A doação e a troca de partes do corpo humano só são factíveis através da mediação técnica de pesquisadores, médicos e de outros profissionais da área da saúde, que possibilitam a transformação de partes do corpo humano em mercado. Sem essa mediação elas não teriam nenhum valor de uso, tampouco valor de troca (Berlinguer e Garrafa, 2001).

A combinação de tecnologias biomédicas e ações de mercado permitiu o rápido surgimento de formas imprevistas $e$ incontroláveis de comercialização das funções reprodutivas. As diferenças ou marcadores sociais, anteriormente identificadas na superfície ou no interior do corpo, passam a estar inscritas nos genes. $\mathrm{O}$ entusiasmo com que foi divulgado o projeto de mapeamento genético humano trouxe a idéia de que o corpo e a

${ }^{2}$ Essa discussão faz parte da pesquisa de Doutorado em Ciências Sociais (Ramírez-Gálvez, 2003), com orientação da Profa. Dra. Mariza Corrêa (a quem sempre serei muito grata) e financiada pela FAPESP. 
vida são um mapa digital - informação - decodificável e, em conseqüência, no futuro as doenças poderão ser resolvidas na origem ou através da terapia genética.

Apesar de certa decepção com os resultados do Projeto Genoma, pelo fato de não serem identificados genes responsáveis por algumas habilidades e "desordens" (como dislexia, homossexualidade, espírito aventureiro, etc.), a promessa de encontrar a "verdade nos genes" parece ter promovido certos efeitos. Essa questão se enquadra no que Finkler (2001) afirma ser a conceitualização contemporânea de transmissão hereditária, construída na base de concepções euro-americanas de parentesco e família, como concebidas por Schneider (1968). Isto é, das relações familiares e de parentesco serem estabelecidas pela reprodução e os vínculos de sangue. O parentesco é análogo à biogenética, no sentido dos parentes serem constituídos na partilha do material genético - conceitualização pautada na perspectiva científica de contribuição biogenética de pai e mãe em iguais proporções. O grau de parentesco e identificação dos parentes pode ser calculado em função do DNA partilhado.

Merece destaque, nesta parte, o argumento de Finkler sobre a inclusão da família e do parentesco como parte das experiências humanas a serem medicalizadas. A biogenética constitui um tipo de inspeção na qual prevalece a compreensão biomédica na etiologia das doenças, que localiza e enfatiza a falha nos genes. A autora observa que tanto na relação médico-paciente, como nos meios massivos de comunicação há a tendência de enfatizar o vínculo biológico em função da associação entre parentesco e saúde. A noção de risco genético tornou-se uma doença em si mesma. Nesse panorama, alguns estados norte-americanos criaram leis que permitem às pessoas adotadas obter a identidade dos pais genéticos para ter acesso a seus prontuários médicos, considerando-se que a história médica é parte da identidade e da memória das pessoas.

A exaltação do vínculo entre doença e parentesco tem influenciado o cotidiano de muitas pessoas. A origem biológica se 
tornou, no ver de Finkler, fundamental para o destino, uma espécie de dialética entre antecipação do futuro e relembrança do passado. A história médica recapitula a história do parentesco perdida na memória dos indivíduos, expande seu olhar às relações consangüíneas, estruturadas sobre a concepção de uma identidade genética bilateral que permeia crenças e práticas sociais. Em pesquisa realizada com pessoas adotadas, a autora menciona os conflitos internos frente à falta de uma história médica da família biológica. Todavia, as dúvidas não se restringem à procura de uma biografia ou à falta de informação sobre a pré-disposição ou risco para desenvolver certas doenças, como também à procura de explicações para suas preferências, gostos e habilidades.

Acerca desta tendência, Nelkin (2001) vai além da medicalização do parentesco ao considerar, também, sua mercantilização, lembrando que o DNA não é só um conjunto de moléculas, mas um poderoso conjunto de representações culturais. ${ }^{3}$ As crenças no determinismo genético impulsionam a notável expansão da indústria da tecnologia reprodutiva. $\mathrm{O}$ discurso sobre reprodução é difundido por imagens de bancos, propriedade, produtos, realização; óvulos e espermatozóides são bens de consumo avaliados de acordo com seu valor genético. $\mathrm{Na}$ era da genética, empreendimentos comerciais - como o uso do teste de DNA para corroborar paternidade ou empresas especializadas na busca de parentes biológicos - têm proliferado para ajudar às pessoas a traçar sua genealogia.

Contudo, a mercantilização do parentesco não se dá unicamente na reconstrução da história familiar, mas também na seleção e programação da carga genética dos tecno-filhos. A possibilidade de detecção de potenciais doenças genéticas no

${ }^{3}$ Fonseca $(2002,2004)$ oferece uma interessante análise acerca do crescimento $e$ as implicações do uso deste teste no Brasil. Segundo a autora, embora a realização de testes de DNA não seja a principal atividade de um laboratório, representa a maior fonte de rendimentos do mesmo, gerando uma forte disputa pelo mercado entre laboratórios públicos e privados. 
embrião tem gerado negócios lucrativos. A escolha de gametas por catálogo e de mães substitutas, nos Estados Unidos, divulgada amplamente pela internet, são um bom exemplo:

Os futuros pais podem escolher desde o tipo de gestação pretendida (com ou sem barriga de aluguel, com doador de sêmen ou de óvulos, entre outros) até o tipo físico e genético dos doadores. Gasta-se em média de US\$18 mil a US\$60 mil por um contrato de geração de bebê (Bebê, 2000).

Alguns autores apontam a maternidade substituta (surrogate motherhood) como uma clara expressão da mercantilização do corpo feminino e de suas capacidades reprodutivas. Esta prática é considerada como manifestação típica da chamada venda de uso - troca de funções corpóreas por moeda. Nos Estados Unidos, a maternidade substituta é uma instituição burocratizada que envolve intermediários, complexos contratos e remuneração ${ }^{4}$, similar à intermediação para recrutar doadoras de óvulos. Os jornais e páginas eletrônicas trazem, em detalhes, as características desejáveis de uma doadora de óvulos (inteligência, beleza, modos, tamanho corporal e porte), que parecem determinar o valor dos "serviços". Um exaustivo formulário, que deve ser preenchido pelas potenciais doadoras de óvulos, indaga características físicas, religião, se usa lentes para correção de problemas visuais, lateralidade, presença de sardas, habilidades em matemática, ciências, literatura e atléticas, talentos artísticos, uso de tabaco, álcool e outras drogas, problemas mentais - depressão, esquizofrenia, doença bipolar, anorexia ou bulimia, automutilação, desordens obsessivo-compulsivos (Center for Human Reproduction, Egg Donor Application). A indagação desses últimos aspectos não faria sentido se estes não fossem considerados susceptíveis de transmissão genética.

4 Para uma etnografia completa destes serviços nos Estados Unidos, Cf. Ragoné (1994). 
Ainda que no Brasil a maternidade substituta e a venda de óvulos sejam práticas proibidas nos termos que se organizam $e$ disponibilizam em outros países ${ }^{5}$, a chamada venda de uso se apresenta de outra forma, como na criação do programa de doação compartilhada de óvulos ${ }^{6}$ (Lopes et alii, s/d) implementado por várias clínicas de RA. A ausência de leis, no sentido estrito, no país e a configuração de uma prática da RA trans-nacional, desde suas origens, permitem a troca de programas de venda de gametas por catálogo, como divulga a imprensa local (Almeida, 1999; Carelli, 2001).

A comercialização do material humano, condenada nos valores tradicionais nos quais a descendência teria um valor incomensurável, é amenizada com a retórica da dádiva, do apelo à filantropia, levando algumas mulheres a se submeter aos riscos desses procedimentos com o intuito de mitigar o sofrimento das que não podem engravidar ou levar uma gestação a termo. A retórica da dádiva mascara a relação com a mercantilização de partes do corpo, silenciando qualquer discussão acerca da mesma (Sharp, 2000).

Adicionalmente, as narrativas sobre a promoção de serviços de RA ou de programas especiais como o de doação partilhada de

${ }^{5}$ Nos Estados Unidos existem companhias especializadas para recrutar $e$ oferecer serviços de maternidade substituta, numa linguagem claramente comercial, ainda que amenizada pelo incalculável milagre da vida. A empresa ICNY, com sede em Nova Iorque, mas operando em 15 países, envia folheto a ginecologistas explicando as vantagens e procedimentos de seu trabalho. $\mathrm{O}$ material é composto de fotos de crianças e depoimentos de pais - "o nosso amor e a nossa gratidão por nos ter feito descer do céu o nosso presentinho" -, acompanhado de indicações sobre forma de inscrição, o pagamento $e$ as garantias da saúde física e mental das mães substitutas, assim como do contrato que garante a renúncia, por parte delas, a qualquer direito de parentesco (Berlinguer e Garrafa, 200:110).

${ }^{6}$ Este programa consiste na troca de óvulos por tratamento. Mulheres com condições financeiras, mas que não possuem óvulos adequados para serem inseminados, pagam os medicamentos usados para estimulação ovariana em mulheres de serviços públicos que, em troca, devem "doar" parte de seus óvulos. 
óvulos, ou o parcelamento dos tratamentos, pressupõem, mobilizam e reforçam normas e valores associados à maternidade e/ou à reprodução, como se aprecia nas imagens publicitárias dos laboratórios farmacêuticos.

\section{Habilitando a natureza}

No caso dos folhetos de medicamentos para RA, observamos certa homogeneidade e reiteração nos conteúdos e imagens. A imagem utilizada pelo laboratório Serono, para promover o Cetrotide ${ }^{7}$, nem sempre aparece acompanhada de texto ou repete a mesma frase: tornando a vida mais fácil desde o seu início, traduzida para português, espanhol ou inglês, segundo o local de circulação do folheto. Possivelmente a imagem dispense o texto, pois se trata de uma imagem "clássica" do amor materno: uma mulher que carrega prazerosa e amorosamente um bebê no colo.

A pesar de o apelo dos laboratórios às imagens e frases que exaltam os valores ligados à maternidade, mais especificamente os atribuídos à maternidade biológica, a geração tecnológica é considerada um milagre. Possivelmente este seja um dos maiores empreendimentos do mundo contemporâneo, que fica nas mãos do médico ou depende de sua assistência para sua realização, colocando o especialista no lugar de gestor de vida. Os medicamentos e a intervenção médica tornam-se condições imprescindíveis para sua realização, como parece sugerir outra imagem (Laboratório Serono - Gonal F) na qual um bebê parece flutuar ligado, através de um objeto que simula um cordão umbilical, a uma caixa de medicamento.

A ligação do bebê à caixa de medicamento, tecnologiza a produção da vida. A imagem lembra a análise de Petchesky (1987)

7 Medicamento indicado para a prevenção de ovulação prematura em pacientes submetidas à estimulação ovariana controlada para coleta de oócitos a serem usados com técnicas de reprodução assistida. Monografia do produto. Laboratório Serono. 
acerca da visualização do feto mediante o ultra-som, como se fosse uma entidade flutuante, não contida. Mas, nas imagens usadas na RA não se trata de fetos e sim de bebês "prontos", com a beleza e a certeza de sobrevivência que ganham alguns meses depois do nascimento. O bebê da figura descrita tem autonomia da mãe, mas não do medicamento. Desloca-se o poder de geração da vida da mulher para o medicamento, cuja efetividade depende, entre outros fatores, da habilidade do médico para indicar a dose certa nos casos certos. Essa imagem parece seguir a mesma lógica de outra propagando do mesmo laboratório, na qual um ou uma profissional da medicina segura um bebê nas mãos, com o sugestivo texto: Às vezes até os milagres necessitam de uma pequena ajuda...

A imagem parece indicar o momento do parto, cena na que tampouco aparece a mãe. O medicamento e o especialista constituem os protagonistas da geração da vida, o helping hand, que sugere parte das estratégias através das quais se coloca em "evidência" a ineficiência da natureza e o domínio da mesma mediante a biotecnologia. Em artigo publicado em 1993, Franklin apresenta a imagem de uma propaganda de Serono, composta em duas partes, com um texto similar ao anterior: "Se a natureza não pode entregar... Com a ajuda de Metrodin você pode" [If nature can't deliver... with Metrodin's help you can]. 

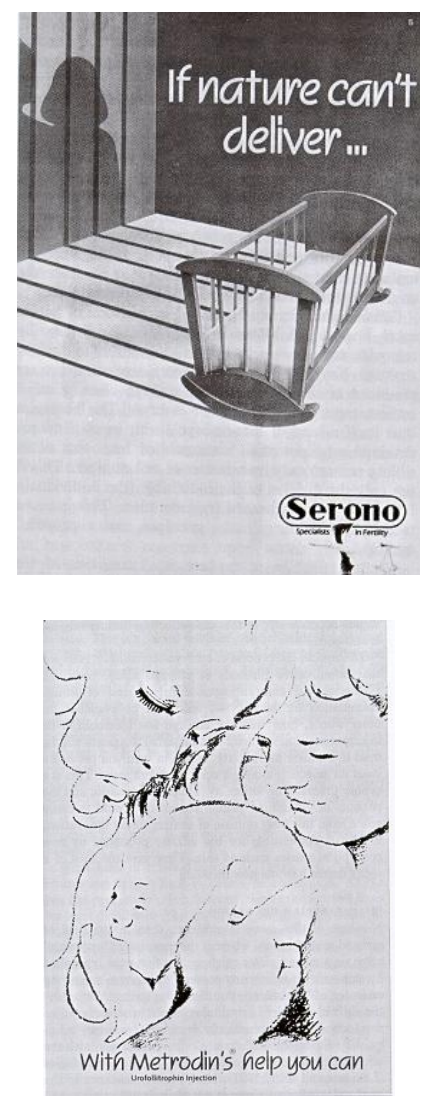

Figura 1

Propaganda Laboratório Serono - Metrodin

No entanto, as imagens são diferentes. Na primeira, aparece o desenho de um berço vazio, cujas barras se refletem na parede $e$, atrás delas, a sombra de um casal. A sobreposição das barras sob a sombra do casal sugere a idéia de prisão, possivelmente uma condenação imposta pela infertilidade. Na segunda, acompanhada do texto "Com a ajuda de Metrodin você pode", aparece o desenho do casal com um bebê no colo e rostos delineados. $\mathrm{O}$ medicamento parece permitir a passagem da 
escuridão, produzida pela infertilidade, à luminescência na qual os sujeitos adquirem uma identidade, um rosto e a completude.

A publicidade dos laboratórios parece ser a mesma para todos os países, como sugerem os mesmos folhetos que circulam em diferentes idiomas e as análises realizadas por Franklin (1993) no Reino Unido. As imagens exploram o momento de fecundação e divisão celular que, como manifesta Chazan (2007), não tem referentes no mundo "real", objetivando o processo de reprodução como um evento científico e tecnicamente capturado, que aconteceria de igual maneira em qualquer contexto social ou cultural. Essa questão pode ser considerada como um dos efeitos materiais da tecnologia visual, isto é, o alargamento da representação do processo reprodutivo a estágios cada vez mais anteriores, que possibilitam, inclusive, a adjetivação dos gametas e sua descontextualização dos corpos que os produzem.

$O$ conteúdo dessas imagens é um efeito material do processo de configuração da RA, enquanto constituem formas de dar sentido e atribuir significados à assistência médico-tecnológica da reprodução, isto é, constituem "operadores culturais" orientados à introdução, difusão e aceitação de novas formas $e$ conceitos de produzir vida. As imagens abrem espaço para a comunicação de acesso a outras possibilidades de significação, alargando o universo de representação tradicional da reprodução.

A intervenção tecnológica na reprodução viria a superar a ineficiência da natureza, através da habilidade e da capacidade dos especialistas para sua execução; monitoramento, manipulação e controle do fenômeno da criação "divina". A publicidade orientada aos especialistas da RA explora valores tradicionais ligados à maternidade biológica e à configuração da família nuclear $e$, a princípio, parece não se diferenciar dos valores exaltados nas propagandas orientadas para a/os potenciais usuárias/os dessas tecnologias. No entanto, algumas diferenças podem ser identificadas. O deslocamento ou ausência da mulher, em conseqüência da centralidade atribuída ao médico e à técnica (física ou química) nas propagandas dirigidas aos profissionais, é 
amenizado nas imagens dirigidas às/aos usuários destes serviços, que priorizam imagens de óvulos, espermatozóides, bebês e famílias "completas".

Como observa Maingueneau (1993) acerca da produção discursiva no campo científico, não podemos afirmar que todos os especialistas, envolvidos em diferentes níveis nesse campo de atuação, tenham o mesmo grau de envolvimento nas redes nas quais se produzem os discursos e a imagística da RA, no entanto, essa produção representa uma condição essencial da constituição e funcionamento do campo.

O universo da RA é colocado ao alcance das/os potenciais usuárias/os, mediante um discurso padronizado acerca da infertilidade e das possibilidades de RA. É recorrente o apelo ao desejo de ter filhos como um anseio natural, cuja realização é um direito ao qual todas as pessoas têm que ter acesso. O justo, nessas narrativas, é pelo menos tentar esgotar os recursos que a tecno-ciência disponibiliza para superar as dificuldades e limites impostos pela natureza, como a idade, por exemplo.

Essa representação moderna da infertilidade alude ao desespero das mulheres, ao sofrimento ocasionado pela falta de filhos, na perspectiva de indicar o beneficio da utilização das tecnologias reprodutivas, que possibilitariam o nascimento do "bebê milagre" (Pfeffer, 1993). Como indica Franklin (1997), o moderno mito da infertilidade apela à emoção do casal, à esperança como uma forma de apresentar o sucesso médicotécnico, que proporciona uma óbvia e aparente naturalidade à capacidade da ciência e à "esperança da cura médica".

Técnicas como a Fertilização in-vitro (FIV) e a Injeção Intracitoplasmática de Espermatozóide (ICSI) representam uma ruptura, um novo paradigma no tratamento da infertilidade e a subversão da biologia da reprodução. A FIV possibilitou a fecundação, driblando problemas funcionais como a obstrução tubária, mas deslocada do corpo da mulher; a ICSI permitiu alterar 
mecanismos de seleção natural ${ }^{8}$, atuando no nível celular, ao possibilitar a reprodução de homens sem espermatozóides e; finalmente, a promessa da fabricação de óvulos no laboratório no nível da engenharia genética - representa a completa dessexualização da reprodução, ao ser possível a produção da vida a partir de células somáticas. Nessas rupturas identificamos também o deslocamento do que é considerado natural: da forma de reproduzir para o desejo de reproduzir.

A aceleração também parece ser uma das características essenciais desse campo. Em poucos anos, técnicas consideradas revolucionárias (como a FIV) se tornaram tradicionais, ao surgirem outras mais sofisticadas, disponibilizadas em períodos extremamente curtos, considerando o tempo necessário para a avaliação de suas implicações, que não atinge apenas seus consumidores e os indivíduos produzidos por essas tecnologias, mas também as futuras gerações. Nesse universo, observa-se com entusiasmo a consagração do novo e do inédito:

a aceleração tecnológica e econômica é tal que até mesmo o atual acaba sendo ultrapassado: tudo o que é... já era. (...) a atenção concentra-se não no que é, mas no vir-a-ser. $\mathrm{O}$ olhar se volta para o futuro; melhor dizendo: para a antecipação do futuro (Santos, 2000).

Se pensarmos na evolução das técnicas e observarmos o foco na procura das causas da infertilidade, notamos que, num momento não muito distante, esta era atribuída à mulher, objeto de exaustivas avaliações para determinar, especialmente, fatores de ordem funcional. Mais recentemente, construiu-se o conceito de casal infértil, com o qual, entre outras questões, abriu-se o campo de reprodução humana que envolve um maior número de

8 O princípio de seleção natural, da teoria darwinista, tem sido problematizado e pensado por outros autores como uma relação de forças não-naturais. Não desconhecemos o mérito dessa discussão que, ainda que cara a este trabalho, ultrapassa nossos limites. Cf. Santos (2003). 
especialistas. A procura da infertilidade se realiza, cada vez mais, no nível micro, alargando o leque de situações e contextos para a indicação tanto de tecnologias diagnósticas como de intervenção. Potentes tecnologias de visualização parecem consagrar os óvulos como objeto privilegiado de indagação. A infertilidade poderia estar determinada pelo envelhecimento dos óvulos, susceptível de ser superada mediante uma plástica do óvulo, um rejuvenescimento, possível através da troca de citoplasma ou do núcleo.

$\mathrm{Na}$ promessa de sucesso das técnicas de RA, a eficácia real parece mascarada por estratégias que indicam diversas taxas: gestação/transferência, gestação/ciclo, fertilização, clivagem, implantação; gravidez clínica, bioquímica, bebê em casa e taxa de cada técnica relativizada por idade. As taxas de sucessos são expressas em termos tão complexos e confusos como os anteriores, ou são absurdamente simplificadas como na matéria Tudo por um filho da revista Veja, na que se divulgou que "Nove em cada dez casais brasileiros inférteis conseguem ter um filho com a ajuda da medicina" (Carelli, 2001). De qualquer forma, o entusiasmo e a promessa, assim como as tentativas para reduzir custos e aumentar o acesso da população à RA facilitam a aceitação pública e estimulam sua procura, aspecto que se torna fundamental para sua legitimação. Esta também se encontra atrelada à mobilização de convenções reconhecíveis e tradicionais que evocam a concepção de filhos com material genético partilhado, para a configuração de uma "verdadeira" família (McNeil, 1993).

Os depoimentos de casais e mulheres também são formas de validação das tecnologias nas quais a criação Divina é reapresentada. Emotivos depoimentos de casais ilustram a superação da infelicidade e do desespero ocasionado pela infertilidade graças à intervenção médico-tecnológica, através da qual conseguem conformar uma família. De alguma forma, como indica Franklin (1999), proporcionar a felicidade a esses casais, 
mediante o filho biológico, protege os especialistas da censura que poderia surgir ao se colocarem no lugar de Deus.

A FIV e outras tecnologias mais recentes introduziram uma ruptura na continuidade do processo feminino de procriação, ao possibilitar a ocorrência da gravidez sem sexo e a fecundação fora do corpo, substituindo uma função corporal. No entanto, elas não buscam restaurar uma deficiência nas funções do corpo. Elas se consagram, em si mesmas, como a função. Esse desenvolvimento se torna possível no modo de compreensão da reprodução como um processo de causalidade de eventos e mecanismos que podem ser fragmentados e influenciados independentemente. Tal forma de conceitualizar a reprodução permite dissecar todo o processo em seqüências de estágios autocontidos, isolados e manipuláveis (Kirejczyk, 1993). A tecnologia reprodutiva, ao substituir algumas das funções corporais, desloca o lugar central das mulheres no processo reprodutivo e sua capacidade de agenciamento.

Ainda que a falta de descendência seja redescrita em termos médicos, sua intervenção não se configura mais como processo de cura, senão como facilitador para a constituição de uma família. A intervenção médica sobre a infertilidade reforça o papel da medicina na construção de significados em torno da sexualidade e da prescrição de procriação. A medicina passa de sua função de cura para uma função política de criação e transmissão de normas sobre o corpo, a saúde e o comportamento no contexto da biopolítica (Foucault, 1997). Esse domínio se exerce mediante a criação ou incitação de desejos ligados a identidades específicas $e$ ao estabelecimento de normas com as quais os indivíduos, seus comportamentos e corpos são julgados.

Nessas narrativas, a explicação de como a concepção acontece espontaneamente produz um alargamento na compreensão da produção da vida e a reiteração de tudo o que pode dar errado. A fragmentação do processo, sua redução à expressão molecular e o fato de tornar o corpo transparente deixam em evidência a "ineficiência" da fertilidade humana, argumento que, por sua vez, justifica a necessidade de a 
tecnologia dar uma mãozinha à natureza: "Tantas coisas podem ocorrer desde a fecundação do óvulo ao nascimento de uma criança que sempre acho um milagre termos a maioria dos bebês nascendo perfeito..." (Gleen Dosman, do Institute for Achievement of Human Potencial, citado na página do Instituto Paulista de Ginecologia e Obstetrícia). As narrativas sugerem, também, uma melhor eficiência da tecnologia na reprodução, que superaria a natureza.

Segundo Franklin (1993), o discurso sobre RA (na mídia, nas publicações científicas, nos debates legislativos e éticos) desafia alguns supostos que embasavam conceitualizações prévias. Um deles aponta que o processo reprodutivo é retirado de uma naturalidade ou reinscrito numa versão de "naturalidade", que é alterada pela maneira em que ela é assistida. Nessas narrativas, a tecnologia joga um papel significativo: através dela, o mundo da reprodução torna-se visível e reconhecível de novas maneiras. A criação de novas formas de acesso à reprodução permite apreciar e salientar o potencial da assistência tecnológica ao processo reprodutivo.

A tecnologia seria reveladora de quanto a natureza necessita de assistência, ao flagrar sua própria ineficiência. O helping hand da assistência tecnológica se funde com a natureza e ao mesmo tempo a desloca. Ela pode assistir à natureza ao superar sua falha. Isto é, fazer o que esta teria feito naturalmente, indicando o caráter substituível entre natureza e tecnologia. Este é um ponto chave na mudança do significado cultural acerca da reprodução, cuja importância está na legitimação e naturalização da assistência ao processo reprodutivo. Paradoxalmente, como afirma Franklin, uma legitimação através da naturalização.

Consideramos que essas narrativas não se restringem a colocar em evidência a ineficiência da natureza, mas também a flagrar a falta de adaptação da natureza ao mundo contemporâneo. Isto é, as tecnologias permitiriam superar $e$ expandir os limites dentro de uma natureza que teria ficado pequena para dar conta do mundo contemporâneo. A natureza 
ficou pequena, particularmente para a reprodução tardia, que se tornou o grande desafio nas pesquisas da RA.

As técnicas de doação de óvulos, troca de citoplasma ou do núcleo, crio-preservação de tecido ovariano, fabricação de óvulos no laboratório têm como alvo principal mulheres cuja fertilidade entrou em declínio em função da idade e para as quais a natureza não daria mais opção. Nesses casos, o leque de tecnologias complementares (Assisted Hatching ${ }^{9}$, Spindle view ${ }^{10}$, o Diagnóstico Genético Pré-Implantacional ${ }^{11}$ ) também se expande, com a justificativa de selecionar os melhores embriões e de aumentar as chances de uma gestação e uma criança normal.

$\mathrm{O}$ material analisado reitera a necessidade da RA em função das mudanças do mundo contemporâneo, do qual o adiamento da maternidade parece ser uma de suas características. A natureza estaria se comportando de maneira injusta frente ao processo mundial de adiamento da maternidade à qual a ciência responde, "devolvendo à mulher o direito reprodutivo que o tempo roubou". Desse modo, nas narrativas, as NTRc não só proporcionam um helping hand à natureza, como também a substituem, cobrindo os buracos deixados pelo seu estancamento em relação às demandas do mundo atual.

\section{Da alcova ao laboratório}

Assistir a fecundação não só significa auxiliar o processo de fecundação. Também pode significar ver, observar, testemunhar, desde casa, a fecundação feita no laboratório. Uma clínica de São Paulo, por exemplo, oferece a suas usuárias o acompanhamento,

9 Técnica que permite, antes da transferência, realizar uma abertura mediante agentes químicos ou a laser na membrana externa do embrião, para melhorar a implantação do embrião.

${ }^{10}$ Equipamento que permite a visualização dos cromossomos dos óvulos e a seleção dos melhores.

${ }^{11}$ Biopsia de embrião para identificar e excluir os embriões que são portadores da desordem genética 
passo a passo, da evolução do "bebê", da concepção às vésperas do nascimento. Os casais, através da internet e mediante uma senha, têm acesso às imagens de cada etapa do processo de fertilização, passando pela formação do embrião até o desenvolvimento do bebê. "Queremos promover a participação dos pais na gestação de seus filhos", afirma Paulo Perin, médico especialista em fertilização da clínica Diason (Novo Milênio, 2002; Ebonet, 2002).

Desse modo, essa clínica se propõe tornar o processo mais transparente para mães e pais envolvidos. Semelhante ao casal que engravida sem intervenção médica, que se emociona com as imagens de ultra-sonografia que lhe conferem uma "identidade" ao ser em gestação, os donos da clínica antecipam esse momento para a fecundação. Com o tradicional copie-e-cole, os futuros pais e mães transferem a imagem para seu computador, imprimem em alta resolução e montam o álbum do bebê incrivelmente completo.

Rosana, que acompanhou todo o processo de fertilização in vitro acessando a Internet de sua casa, atesta a comodidade que o sistema oferece (Novo Milênio, 2002).

Observa-se uma clara ruptura com a convenção que colocava a reprodução como resultante da conjunção dos corpos, numa troca erótico-amorosa. O que antes era narrado como um ato privado, de intimidade e segredo, torna-se um ato público, um procedimento médico e assepticamente orientado e controlado, mediado por trocas econômicas.

A mesma clínica também estabelece que a decisão de cancelamento do ciclo de RA deve ser tomada pelo médico a partir dos resultados dos exames realizados durante a estimulação da ovulação. Em caso de falha na tentativa iniciada, a clínica encoraja aos casais para não observar tal fato como um fracasso $e$ sim como uma forma de proteção frente à decepção que poderia ocasionar um resultado negativo de gravidez. Ainda que a 
promessa de realização do sonho se mantenha, as clínicas advertem para a necessidade de realizar vários ciclos de RA. Afirma-se que um resultado negativo não deve ser desanimador, pois permite à equipe realizar uma avaliação e passar para um próximo ciclo, corrigindo as possíveis falhas anteriores. Desse modo, o fracasso do procedimento não é absoluto. Tanto o sucesso quanto o fracasso são avaliados conforme os procedimentos anteriores e redefinidos durante e depois de cada tentativa.

A imagem da cegonha é bastante explorada por várias clínicas na animação das páginas eletrônicas. De fato, é uma imagem apropriada para representar a reprodução sem sexo. A história da cegonha, uma mentira tradicional contada às crianças para ocultar a sexualidade dos pais, no contexto da RA, tornou-se real. As crianças são geradas sem sexo, num lugar especializado $e$ distante do espaço íntimo e reservado dos pais.

Além do deslocamento que deserotiza e fragmenta a reprodução, anotamos a seguir a transformação das partes do corpo em commodities. A commodificação do corpo é compreendida aqui como uma forma de objetivação, transformação das pessoas e seus corpos de uma categoria humana a objetos de uma economia de desejo, mediante diversos modos: medicalização da vida, fragmentação do corpo, coisificação de indivíduos e categorias de pessoas (Sharp, 2000). O corpo não só é fragmentado, mas também "bioinformatizado" na fusão de informática com a biologia, o que permite reprogramar e recombinar "os textos da vida humana e do ambiente humano" (Carneiro et alii, 2000), tornando-se fonte de matéria-prima, como indica Santos (2001), suscetível a processos tecnológicos que lhe agregam valor.

As pessoas colocam a matéria prima e esperam que seja processada. Os múltiplos fracassos dos procedimentos de RA são utilizados para encorajar a realização de mais ciclos, nos quais se espera corrigir as possíveis falhas das tentativas anteriores. Contudo, a disposição para se submeter às diversas tentativas sem 
garantia de conseguir o almejado filho requer um desejo de maternidade "naturalizado, atávico e despótico", que leva a fazer "tudo por um filho". Não basta, então, que o desejo de descendência seja social, possível de satisfação mediante a adoção de crianças. Ele deve ocupar um lugar primordial, inelutável, inscrito nos genes pela nossa herança evolutiva, necessário à sobrevivência dos indivíduos e da espécie, como aparece em Silver (1997), Abdelmassih (1999) e nas diferentes páginas eletrônicas das clínicas de RA.

Franklin (1997), em pesquisa realizada com mulheres que fizeram FIV na Grã-Bretanha, observou uma brecha entre a esperança de sucesso $e$ as possibilidades reais de alcançar $\mathrm{o}$ desejado filho mediante RA. A infertilidade aparece como um obstáculo à progressão, considerada normal e natural, de realização da identidade feminina e da conjugalidade. As narrativas destas mulheres parecem se fundamentar na ambigüidade e na contingência, mais do que na certeza; na convenção do romance no qual se espera superar, de forma heróica, grandes obstáculos que conduzam a um final feliz, em concordância com as normas convencionais de unidade da função conjugal e procriativa. A expectativa, o entusiasmo e a fé na tecnologia indicam que o risco não está nela mesma, mas nas contingências que desviam o caminho para atingir o desejo.

A mesma autora destacou o processo de RA, especificamente de FIV, como um estilo de vida para a mulher e a familia, como aponta uma de suas informantes: Você vive, come, bebe - tudo em função da FIV. Nada mais existe... Eu não estava interessada em outra coisa. Se a RA é vista como uma via para a realização do desejo, a tentativa deve ser, pelo menos, feita. A busca do filho através da RA se torna um fim em si mesmo. Barbosa (1999) observa que muitas das mulheres brasileiras entrevistas na sua pesquisa apontam a rotina da RA como uma dificuldade a ser administrada em conjunção com as demandas do trabalho remunerado. Os freqüentes fracassos, que levam à repetição das tentativas, tornam a relação entre as demandas 
reprodutivas e produtivas ainda mais complicadas, conduzindo, em muitos casos, ao retiro voluntário do emprego ou à demissão.

Os dilemas e esperanças, manifestos na perseguição do bebê milagre, $e$ as complexas negociações entre o sucesso $e$ fracasso da tecnologia conceptiva de última geração ilustram a intensidade com a qual, literalmente, se incorpora o progresso científico. A imagem da mulher desesperada pela falta de filho, usada nas estratégias publicitárias da RA, supõe, como contrapartida, a imagem salvadora do universo tecnológico como expressão do inelutável progresso científico. Mas, também precisa de uma devoção ao progresso científico e tecnológico e de uma disposição e capacidade de incorporação do mesmo Franklin (1997). Os fatos biológicos da reprodução não são somente simbólicos no sentido de criar redes de parentesco, mas também são formas particulares de conhecimento, de acesso à verdade, com poder de instrumentalização. Tanto a biologia quanto $\mathrm{O}$ conhecimento da biologia são dotados de poder gerativo, no sentido de a função biológica poder ser assumida tecnologicamente.

Nesta pesquisa não foram exploradas a fundo as narrativas das mulheres e/ou casais usuárias/os de RA. As referências deste grupo foram emprestadas de outros estudos. Mas, consideramos fundamental traçar o perfil de usuárias das NTRc no país, não só na perspectiva de acesso a esse universo, mas tendo presente as considerações sobre a diversidade de posições no espaço social que determinam estilos de vida diferentes, diferenças simbólicas objetivadas nas condições de existência de cada grupo, que se exprimem no gosto e na apropriação tanto material quanto simbólica de objetos ou práticas (Bourdieu, 1994). Cogitamos que nessa lógica da especificidade dos espaços simbólicos, associada à classe social, a incorporação do progresso tecnológico como valor e estilo de vida pode ser significado de diversos modos, segundo o capital econômico e simbólico, uma vez que a RA reforça valores burgueses sobre o determinismo biológico ou genético. 


\section{A fabricação da vida}

A inserção do mercado na produção da vida pode ser compreendida num contexto de transição ou mudança do capitalismo contemporâneo. Segundo Rifkin (1999, 2001), a base da vida moderna, na qual propriedade e mercado eram sinônimos, começa a se desintegrar para dar surgimento a outras formas de valor na nova economia de mercado de produção cultural. A comercialização do acesso a experiências culturais que, levadas à arena comercial, são transformadas em commodities, seria uma das conseqüências de um novo "hipercapitalismo". O acesso às experiências vividas torna-se tão importante quanto foi o acesso à compra de propriedades numa época anterior. Nesse sentido, a pergunta não é mais o que se quer ter e sim o que se quer vivenciar.

As mudanças na economia global são produto da grande revolução tecnológica do século XXI, que surge da aliança entre as ciências da computação e a genética, constituindo uma única força tecnológica e econômica. Essa "virada" é produzida pela junção de forças sociais e tecnológicas que configurariam uma nova "matriz operacional" composta, entre outros, pela capacidade para manipular e explorar genes com fins econômicos específicos; a concessão de patentes do material humano; a apropriação dos recursos biológicos do planeta; a possível alteração da espécie humana através da eugenia; e o uso de computadores para sistematizar e administrar a informação genética e a reinvenção da natureza (Rifkin, 1999).

A hegemonia do gene como modelo explicativo de doenças $e$ questões sociais traz implicações de ordem econômica, conceitual e política. A fragmentação e objetivação, através da tecnologia e da prática médica, expõem o corpo ao mundo das commodities, redefinindo o valor social das pessoas ou de suas partes, promovendo formas de segregação baseadas no genótipo. Os genes se tornam objetos alienáveis que permitem remodelar $e$ reimaginar o corpo e os indivíduos (Sharp, 2000). Esse modelo 
explicativo nega fatores sociais, ambientais e educativos na determinação das situações de indivíduos e grupos, eximindo a sociedade e os indivíduos da responsabilidade de serem sujeitos atuantes da sua própria história (Corrêa, 2002; Ribeiro, 2003). As implicações de ordem política surgem nas considerações sobre quem detém o poder para definir os genes que devem ser conservados e eliminados. Se ao longo da história uns sempre controlaram o futuro de outros, atualmente o controle é exercido sobre as futuras gerações, mediante a manipulação antecipada dos processos da vida biológica (Rifkin, 1999).

Como apontam Nelkin e Lindee (1995) apud Rifkin (1999), o gene está se convertendo num "ícone cultural, um símbolo, uma força mágica" que ganha um papel social e político, ao se lhe atribuir o poder não só de explicar a saúde e a doença, como também de determinar comportamentos, habilidades, preferências, etc.

$\mathrm{O}$ desenvolvimento da biologia molecular, como fator determinante na reinvenção da natureza, constitui um dos fios que conduzem à nova ordem econômica. Esse desenvolvimento abre o caminho para reformular os atributos biológicos em função das idéias e desejos dos homens, gerando um tipo de poder divino para selecionar as características e o futuro biológico das próximas gerações:

As leis da natureza estão sendo reescritas para se adaptarem a nossa mais recente manipulação do mundo natural, permitindo-nos racionalizar a nova atividade econômica e tecnológica do século biotecnológico como um mero reflexo da 'ordem natural' das coisas (Rifkin, 1999:217).

A biotecnologia, mais especificamente a confluência do capital, ciência e tecnologia, parece tomar conta dos domínios da vida social, submetendo-a as leis de mercado. Concordando com Franklin (1993), afirmamos que o campo da RA tornou-se uma 
indústria que oferece, nos termos de uma lógica de consumo, uma série de técnicas, produtos e serviços profissionais no novo mercado da infertilidade.

Se observarmos o que há por trás da medicalização da ausência de filhos, podemos encontrar que haveria a prescrição não necessariamente da fertilidade - uma vez que a tecnologia não só cumpre como também se apropria dessa função -, mas do desejo de filho. Strathern (1992) observa que para haver satisfação nesse empreendimento deve haver o desejo, uma vez que sua ausência seria uma afronta ao significado de sua satisfação. Sem desejo de filho não há infertilidade, e sem tal desejo tampouco haveria procura de serviços de RA.

A tecnologia no final do século XX se colocou a serviço da reprodução humana, fazendo corpos vivos. A fertilidade $e$ a procriação eram eventos considerados na ordem do natural. Atualmente, se há alguma falha na procriação através do intercurso sexual, ela é resolvida pela assistência médicotecnológica. As NTRc são artificiais, mas são apresentadas como sensíveis à realização de um desejo natural de procriação, provocando, dessa maneira, um deslocamento do que é considerado natural. Poderíamos agregar que a conservação de alguma forma de naturalidade do desejo possibilita a divulgação $e$ aceitação dessas tecnologias, assim como também provoca a expansão de sua aplicabilidade, no sentido de redefinir a infertilidade. Ao fragmentar o processo reprodutivo, em que pode haver ou não continuidade genética entre o bebê e o pai e a mãe, o que persiste como elemento natural pode ser simplesmente o desejo de ter filhos por alguma forma diferente da adoção.

Nessa relação entre mercado e RA, se o habilitador em outros campos é o dinheiro, no caso da RA é a escolha (Strathern, 1992), pois a instituição familiar deve ser protegida da idéia de exploração financeira. Assim, a circulação (por doação, venda ou troca) de gametas, úteros e embriões é concebida como atos de altruísmo e não como transações comerciais. Entretanto, como a comercialização de gametas e do uso da doação temporária de 
útero são práticas proibidas no Brasil, o dinheiro constitui um fator determinante, um habilitador dos serviços de RA. Não é necessária uma análise muito refinada para observar a co-existência de uma linguagem altruísta e uma linguagem claramente comercial, que não vende bens, mas sonhos e escolhas.

Talvez uma diferença fundamental entre os serviços de RA dos países do Norte e do Sul seja o enquadramento destes últimos na prática da medicina privada. No Brasil, apesar dos esforços para "popularizar os bebês de proveta", o acesso aos serviços de RA continua limitado pelos altos custos. Num panorama nacional de carência de serviços mais primários em saúde,

um dispositivo de cuidados médicos como a reprodução assistida não poderia ser encontrado senão no setor privado da medicina, reproduzindo em toda sua extensão o que tem sido a história do consumo e da exclusão do consumo nas sociedades contemporâneas (Corrêa, 1997:94).

Teorias, objetos, medicamentos e instrumentos diagnósticos e de intervenção ligados ao campo da saúde são inventados num processo que envolve uma complexa teia de relações e interesse. A biomedicina, particularmente, é considerada como um sistema cultural e, semelhante à ciência, emerge num momento particular na história da sociedade ocidental contemporânea. Finkler (2001) afirma que a ênfase colocada na transmissão genética - o determinismo genético - reativa e reforça a categoria nativa de parentesco bilateral. Nesse sentido, não é surpreendente a ampla aceitação da crença na herança genética que, aliada a autoridade com a que é revestida a ciência no mundo contemporâneo, permite encontrar um terreno propício para a aceitação da medicalização da família e do parentesco e, talvez, da fabricação da vida.

Dessa maneira, paralelamente às mudanças que introduzem as tecnologias na criação da vida, há um redimensionamento da reprodução humana que, ao ser deslocada da alcova para o 
laboratório, ganha características de fabricação da vida. Os tecnofilhos são oferecidos como os produtos de um processo mecânico, que produz bebês socialmente desejáveis, descartando os aspectos não desejados da onto-humanidade. O dom da vida, a dádiva do filho, obscurece a forma mercantilista como eles são oferecidos. A vivência da gravidez, a experiência de ter um filho genético, converteu-se em mercadoria: um sonho a ser estimulado que requer mediação médica e tecnológica para sua realização.

\section{Referências bibliográficas}

ABDelmasSIH, Roger. Tudo por um bebê. $2^{\text {a }}$ ed. São Paulo, Globo, 1999.

AlmeidA, Alexandra. Um novo jeito de ser mãe. Folha de S.Paulo, 26/09/1999, pp.3-8 [Cotidiano].

BARBOSA, Rosana. Desejo de filhos e infertilidade: um estudo sobre a reprodução assistida no Brasil. Tese de Doutorado, Sociologia, Universidade de São Paulo, 1999.

BARROS, José Augusto. A medicalização da mulher no Brasil. In: Wolffers, Ivan; Hardon Anita; Janssen, Janita. O marketing da fertilidade. São Paulo, Hucitec, 1991.

BEBÊ 2000. Fertilização Assistida! A tomada de decisão. Disponível em: http://www.mulher.com.br/colabora/b_2000/fertilização_ assistida.htm [acesso em: 01/08/2001].

BERLINGUER, Giovanni; GARRAFA, Volnei. A mercadoria final: a comercialização de parte do corpo humano. $2^{\mathrm{a}}$ ed. Brasília, Editora UnB, 2001 [1996] [Tradução: Isabel Regina Augusto].

BOURDIEU, Pierre. Gostos de classe e estilos de vida. In: ORTIZ, Renato. (org.) Pierre Bourdieu. Coleção Grandes Cientistas. São Paulo, Ática, 1994 [1976].

CARELLI, Gabriela.Tudo por um filho. Com ajuda de casais dispostos a se arriscar, a ciência está vencendo a infertilidade. Veja, Edição 1699, 9 de maio de 2001, pp.108-115. 
CARNEIRO, Fernanda; EMERICK, Maria Celeste; RochA, Marcos. Genoma Humano: limites ao acesso e uso de gen-tes. In: CARNEIRO, F. e EMERICK, M. C. (orgs.) Limites: a ética e o debate jurídico sobre o acesso e uso do genoma humano. Rio de Janeiro, Ministério da Saúde/Fundação Oswaldo Cruz, 2000.

CENTER FOR HUMAN REPRODUCTION. www. centerforhuman reprod.com [acesso em 16/05/2003].

CHAZAN, Lilian Krakowski. "Meio quilo de gente": um estudo antropológico sobre ultra-som obstétrico. Rio de Janeiro, Fiocruz, 2007, (Série Coleção Antropologia e Saúde).

O corpo transparente: um panóptico invertido? Considerações sobre as tecnologias de imagem nas reconfigurações da Pessoa contemporânea. XXVI Encontro Anual da ANPOCS (GT Pessoa e corpo), Caxambu-MG, outubro de 2002.

Clínica e CEntro de Pesquisa em Reprodução Humana Roger ABDELMASSIH. Tecnologia em favor da vida. Catálogo, 2000; 2003.

Disponível em: http://www. abdelmassih.com.br/ nossosbebes/index1.html [acesso em: 24/03/2000].

CORRÊA, Marilena. Admirável projeto genoma humano. Physis: Revista de Saúde Coletiva. vol. 12, n 2, 2002.

- Tecnologias reprodutivas. Limites da biologia ou biologia sem limites?. Rio de Janeiro, Editora da UERJ, 2001.

As novas tecnologias reprodutivas: uma revolução a ser assimilada. Physis: Rev. Saúde Coletiva, Rio de Janeiro, vol. 7, n 1 , 1997, pp.69-98.

DiASON. Disponível em: http://www.diason.com.br/default.asp? corpo $=$ medrep\&doc $=$ III [acesso em: 18/04/2002].

EBONET. Internet mostra desenvolvimento de bebê de proveta. Disponível em: www.ebonet.net/canais/verprn.cfm?m_id=3417 [acesso em 18/04/2002].

FINKLER, Kaja. The kin in the gene. The medicalization of family and kinship in american society. Current Anthropology, vol. 42, n 2, April 2001. 
FouCAult, Michel. História da sexualidade I. A vontade de saber. Rio de Janeiro, Edições Graal, 1997 [1988].

. Microfísica do poder. Rio de Janeiro, Edições Graal, 1996 [1979].

FONSECA, Claudia. A certeza que pariu a dúvida: paternidade e DNA. Estudos Feministas 12(2), Florianópolis, maio-agosto 2004, pp.13-34.

- A vingança de Capitu: DNA, escolha e destino na família brasileira. In: BRUSCHINI, Cristina; UNBEHAUM, Sandra. Gênero, democracia e sociedade brasileira. São Paulo, Fundação Carlos Chagas/Editoria 34, 2002, pp.269-293.

FRANKLIN, Sarah. Embodied Progress. A cultural account of assisted conception. London and New York, Routledge, 1997.

Postmodern procreation. Representing reproductive practice. Science as Culture, vol. 3, part 4, no 17, 1993, pp.522-561.

INSTITUTO PAULISTA DE GINECOLOGIA E OBSTETRÍCIA. www.ipgo.com.br [acesso em: 01/03/2000].

KIREJCZYK, Marta. Shifting the burden onto women. The gender character of the "in vitro" fertilization. Science as culture, vol. 3, part 4, $\mathrm{n}^{\circ} 17$, 1993, pp.507-521.

LOPES, J.R.C. et alii. Programa de doação compartilhada de óvulos. Jornal Brasileiro de Reprodução Assistida, s/d [199-]. Disponível em: http://www.sbra.com.br/artigo3.htm [acesso em: 14/02/2001].

MAINGUENEAU, Dominique. Novas tendências em análise do discurso. $2^{\mathrm{a}}$ ed., Campinas-SP, Pontes/Editora da Unicamp, 1993.

MANICA, Daniela. Supressão da menstruação. Ginecologistas e laboratórios farmacêuticos re-apresentando natureza e cultura. Dissertação Mestrado, Antropologia Social, Unicamp, 2003.

MCNEIL, Maureen. New reproductive technologies. Dreams and broken promises. Science as Culture, vol. 3, part 4, n 17, 1993, pp.483-506.

NELKIN, Dorothy. Commen to: Finkler, Kaja. The kin in the gene. The medicalization of family and kinship in American society. Current Anthropology, vol. 24, nº 2, April 2001. 
NeLKIN, D.; LINDEE, S. The DNA Mystique: The gene as a cultural icon. Nova York, W.H. Freeman, 1995.

Novo MILÊNIO. Clínica de fertilidade mostra imagens na Web. É brasileira a primeira clínica do mundo a oferecer acompanhamento de ciclos de fertilização pela Internet. Disponível em: www.novomilenio. inf.br/ano02/0202b001.htm [acesso em 24/03/2002].

PETCHESKY, Rosalind. Foetal images: the power of visual culture in the politics of reproduction. In: STANWORTH, Michelle. (ed.) Reproductive technologies. Gender, motherhood and medicine. Cambridge/Oxford (UK), Polity Press/Basil Blackwell, 1988 [1987].

PFEFFER, Naomi. The stork and the syringe. A political history of reproductive medicine. Polity Press, Cambridge, 1993.

RAGONÉ, Helena. Surrogate Motherhood. Conception in the heart. Boulder (USA), Westview Press, 1994.

RAMíREZ-GÁLVEZ, Martha Celia. Novas tecnologias reprodutivas conceptivas: Fabricando a vida, fabricando o futuro. Tese de Doutorado, Ciências Sociais, Unicamp, 2003.

RIBEIRO, Renato. A cultura ameaçada pela natureza. Pesquisa FAPESP Especial: Dupla Hélice, 50 anos, 2003.

RIFKIN, Jeremy. Politizar as novas tecnologias. O impacto sócio-técnico da informação digital e genética. São Paulo, Ed. 34, 2003.

. A era do acesso. A transição de mercados convencionais para networks e o nascimento de uma nova economia. São Paulo, Makron Books, 2001a.

. Perspectivas que a revolução micro-eletronica $e$ a internet abrem à luta pelo socialismo. Seminário "Socialismo e Democracia" Partido dos Trabalhadores, São Paulo, junho de 2001b.

. O século da biotecnologia. A valorização dos genes e a reconstrução do mundo. São Paulo, Makron Books, 1999.

SANTOS, Laymert Garcia. Consumindo o futuro. Folha de S.Paulo, 27/02/2000 [Mais!]. 
SCHNEIDER, D. American kinship: a cultural account. New Jersey, Prentice-Hall, 1968.

SHARP, Lesley. The commodification of the body and its parts. Ann. Rev. Anthropol., vol. 29, 2000, pp.287-328.

SILVER, Lee. Vuelta al Edén. Mas allá de la clonación en un mundo feliz. Madrid, Taurus, 1997.

StONE, Linda. Kinship and Gender. Colorado, USA, Westview Press, 2000.

STRATHERN, Marilyn. Reproduction the future: essays on anthropology, kinship and the new reproductive technologies. Manchester, Manchester University Press, 1992.

VIEIRA, Elisabeth. Prática médica e corpo feminino. Dissertação de Mestrado, Depto. de Medicina Preventiva, Faculdade de Medicina USP, 1990. 